\title{
EVALUASI KINERJA DOSEN UNIV.SARI MUTIARA INDONESIA DENGAN MENGGUNAKAN METODE PREFERENCE RANKING ORGANIZATION METHOD FOR ENRICHMENT EVALUATION (PROMETHEE)
}

\author{
Burhanuddin Damanik ${ }^{1}$, Markus Bangun ${ }^{2}$ \\ Program Studi Sistem Informasi Universitas Sari Mutiara Indonesia \\ Jl. Kapten Muslim No. 79 Medan \\ 11damanikus@yahoo.com, ${ }^{2}$ bangun@gmail.com
}

\begin{abstract}
Abstrak - Penilaian kinerja dosen di Universitas Universitas Sari Mutiara Indonesia dilakukan oleh Lembaga Penjaminan Mutu. Penilaian kinerja dilakukan berdasarkan kriteria yang ada, yaitu penilaian Tri Dharma Perguruan Tinggi, kehadiran bimbingan konsultasi dan penilaian diluar tugas utama. Dalam penilaian kinerja yang dilakukan belum ada software khusus yang membantu proses penilaian, dalam perhitungan nilai juga hanya didapat dari perkalian nilai setiap kriteria dengan bobot, dengan penggunaan metode diharapkan penghitungan akan lebih detail. Berdasarkan kondisi yang ada dibutuhkan suatu sistem yang dapat membantu proses penilaian kinerja dan sistem yang memenuhi kondisi tersebut adalah sistem pendukung keputusan karena sistem dapat membantu mengambil keputusan berdasarkan kriteria yang ada. Sistem pendukung keputusan menggunakan metode Preference Ranking Organization Method For Enrichment Evaluation (PROMETHEE), alasan memilih metode ini karena dalam perhitungan komputasi efisien dan memiliki kemampuan untuk mengukur kinerja relatif dari alternatif- alternatif keputusan dalam bentuk matematis sederhana, selain itu metode ini juga didasarkan pada konsep dimana alternatif terpilih yang tidak hanya memiliki jarak terpendek dari solusi ideal positif, namun juga jarak terpanjang dari solusi ideal negatif. Hasil dari penelitian ini adalah sistem pendukung keputusan dapat digunakan untuk menilai kinerja setiap dosen di Universitas Sari Mutiara Indonesia dengan lebih tepat berdasarkan kriteria yang ada.
\end{abstract}

Kata kunci - Penilaian kinerja dosen, Sistem Pendukung Keputusan, PROMETHEE

\section{PENDAhuluan}

Penyelenggaraan pendidikan di perguruan tinggi tak lepas dari peran dosen. Dosen merupakan tenaga akademik yang bertugas merencanakan dan melaksanakan proses pembelajaran, menilai hasil pembelajaran, melakukan pembimbingan dan pelatihan, serta melakukan penelitian dan pengabdian pada masyarakat (Dirjendikti, 2010). Berdasarkan Undang-undang Republik Indonesia No 14 tahun 2005 tentang Guru dan Dosen, Pasal 51 Ayat (1) Butir b, bahwa dosen berhak mendapatkan promosi dan penghargaan sesuai dengan kinerja akademiknya. Dengan adanya penghargaan atas kinerja dosen diharapkan dapat meningkatkan motivasi di kalangan dosen yang tentunya akan berdampak pada pengembangan manajemen akademik di perguruan tinggi. Selain itu, sistem penghargaan juga merupakan unsur penting dan berperan dalam menumbuh kembangkan suasana akademik, yang pada akhirnya dapat mempercepat perkembangan masyarakat ilmiah masa kini dan masa yang akan datang. Maka sudah sepantasnya bila setiap perguruan tinggi dapat memberikan penghargaan bagi dosen yang memiliki prestasi yang membanggakan bagi perguruan tingginya.

Sistem penghargaan terhadap dosen tersebut diterapkan dengan melakukan pemilihan dosen berprestasi. Proses pemilihan dosen berprestasi tidak lepas dari proses evaluasi Beban Kerja Dosen (BKD) yang harus sudah dilaksanakan sebelumnya, karena salah satu kriteria penilaian yang ada dalam proses pemilihan dosen berprestasi merupakan hasil BKD dan memenuhi BKD merupakan syarat untuk bisa terlibat dalam pemilihan dosen berprestasi. Adapun kelemahan dalam proses pemilihan dosen berprestasi berdasarkan hasil evaluasi laporan kegiatan pemilihan akademisi berprestasi tahun 2010 adalah sebagai berikut. 1. Pelaksanaan pemilihan dosen berprestasi hanya berjalan setelah adanya surat dari Dirjendikti sehingga waktu untuk sosialisasi dan seleksi nya singkat. 2. Masih tingginya tingkat subjektivitas dalam proses pemilihan dimana masih adanya peserta yang dipilih ditunjuk secara langsung tanpa melalui seleksi di unit kerjanya, sehingga hasilnya kurang memuaskan. 3. Kekurangpahaman peserta atas kelengkapan yang harus dipersiapkan untuk mengikuti seleksi menyebabkan keragaman dalam penilaian, sehingga tim penguji kadang terlalu timpang tindih menilai antara peringkat pertama dengan kedua dan ketiga karena kurang optimalnya persiapan peserta.

Berdasarkan kriteria yang telah ditentukan terlihat bahwa proses pemilihan dosen berprestasi merupakan permasalahan yang melibatkan banyak komponen atau kriteria yang dinilai (multi kriteria), sehingga dalam penyelesaiannya diperlukan sebuah sistem pendukung keputusan dengan multi kriteria. Salah satu metode 
sistem pendukung keputusan yang multi kriteria adalah Preference Ranking Organization Method For Enrichment Evaluation (PROMETHEE). Promethee digunakan untuk penentuan urutan (prioritas) dalam analisis multi kriteria. Promethee cukup efektif dalam menyederhanakan dan mempercepat proses pengambilan keputusan dengan pengaplikasian metode yang mudah dan lebih sederhana untuk jumlah kriteria ataupun alternatif yang banyak. Dengan mengacu terhadap permasalahan di atas maka dibuat sistem pendukung keputusan dosen berprestasi yang didalamnya mencakup proses evaluasi Beban Kerja Dosen (BKD) dan pemilihan dosen berprestasi dengan menggunakan metode Promethee. Dengan adanya sistem yang berbasis komputer diharapkan dapat menjadi solusi atas permasalahan yang ada.

\section{TINJAUAN PUSTAKA}

\section{A. Definisi Sistem Pendukung Keputusan}

Sistem Pendukung Keputusan (SPK) dapat didefinisikan sebagai suatu program komputer yang menyediakan informasi dalam domain aplikasi yang diberikan oleh suatu model analisis keputusan dan akses ke database, dimana hal ini ditujukan untuk mendukung pembuat keputusan (decision maker) dalam mengambil keputusan secara efektif baik dalam kondisi yang kompleks dan tidak terstruktur.Sistem pengambilan keputusan merupakan bagian yang tak terpisahkan dari totalitas sistem organisasi keseluruhan. Bahwa sistem organisasi paling tidak mencakup sistem fisik (sistem operasional), sistem manajemen (sistem keputusan), dan system informasi.

Organisasi yang bergerak dibidang produksi maupun jasa, tidak lepas dari problematika manajemen pada umumnya. Perubahan struktur pasar, produk, teknologi produksi, organisasi dan yang lainnya terus terjadi sehingga berpengaruh pada kebijaksanaan manajemen yang dijalankan salah satu kiat untuk menyiasati problematika tersebut adalah dengan mengembangkan serta meningkatkan potensi sumber daya yang tersedia.

Olehkarena itu, penempatan dan pemanfaatan sumber daya pada posisi yang tepat mutlak diperlukan. Dalam hal ini, pengelolaan dan pemberdayaan sumber daya secara tepat sangat berperan karena merupakan suatu pendekatan strategis terhadap pendekatan kinerja organisasi. Untuk itu sangat diperlukan sebuah sistem pendukung keputusan yang efektif, yang tidak memisahkan antara manusia, sarana/prasarana, dan sistem manajemen secara keseluruhan agar dapat mencapai tujuan organisasi. Dalam menjalankan aktivitasnya, sekalipun didukung oleh potensi ekosistem dan aksesibilitas yang serba prospektif, namun disisi lain pengambilan keputusan kerap dihadapkan pada masalah utama dalam penentuan masalah strategis yang sulit direalisasikan akibat persepsi heterogen sejalan dengan kepentingan keputusan masing-masing individu / kelompok yang terlibat dalam pengambilan keputusan. Sementara itu sistem pengambilan keputusan merupakan bagian tak terpisahkan dari totalitas sistem organisasi keseluruhan. Sistem organisasi paling tidak mencakup sistem fisik (sistem operasional), sistem manajemen (sistem keputusan), dan sistem informasi(Suyadi, 2000.)

Sistem fisik (sistem operasional) mencerminkan proses transformasi dari input (masukan) menjadi output (keluaran) melalui serangkaian mekanisme/proses dengan melibatkan sumber daya manusia dan non manusia (mesin, uang, bahan baku, energi, informasi, dan lain - lain).Sistem manajemen yang tidak lain merupakan sistem yang menghasilkan keputusan - keputusan yang diperlukan guna menjamin kelancaran sistem fisik. Oleh karena itu sistem manajemen ini menghasilkan sejumlah keputusan, maka sering pula sistem manajemen ini disebut sebagai sistem keputusan.

Ketajaman keputusan yang dihasilkan dipengaruhi oleh kelengkapan dan keakuratan informasi yang dilibatkan didalam proses pengambilan keputusan itu sendiri. Maka peranan sistem informasi sangat penting dalam menyediakan informasi pendukung keputusan. Informasi ini bisa bersifat vertikal (top-down maupun botton-up), horizontal, ataupun diagonal.Aliran informasi vertikal secara top-down mencerminkan adanya informasi strategis yang diterjemahkan menjadi informasi taktis dan operasional. Aliran informasi horizontal merupakan pertukaran informasi antar bagian atau fungsi yang posisinya secara strukturalberada pada tingkatan yang sama; misalnya antar manajer produksi dan manajer keuangan. Aliran informasi diagonal bisa terjadi antara bagian atau fungsi - fungsi organisasi yang secara struktural berbeda tingkatnya. Dari uraian diatas diperlukan suatu bentuk Sistem Pendukung Keputusan. Tujuannya adalah untuk membantu pengambil keputusan memilih berbagai alternatif keputusan yang merupakan hasil pengolahan informasi- informasi yang diperoleh.

\section{B. PreferenceRanking Organization Method for} Enrichment Evaluation

Promethee adalah satu dari beberapa metode penentuan urutan atau prioritas dalam analisis multikriteria. Metode ini dikenal sebagai metode yang efisien dan simple, tetapi juga yang mudah diterapkan dibanding dengan metode lain untuk menuntaskan masalah multikriteria. Metode ini mampu mengakomodir kriteria pemilihan yang bersifat kuantitatif dan kualitatif. Masalah utamanya adalah kesederhanaan, kejelasan dan kestabilan. Dugaan dari dominasi kriteria yang digunakan dalam Promethee adalah penggunaan nilai dalam hubungan outranking. Menurut Hunjak (1997:161), masalah pembuatan keputusan dengan multikriteria dapat dituliskan sebagai berikut.

$\operatorname{Max}\{f 1(a), f 2(a), \ldots, f k(a): a \in A$ 
Jika A adalah set dari alternatif pilihan yang mungkin terjadi, f1, f2, ..., fk adalah kriteria yang mana telah dievaluasi sebelumnya. Apabila semua kriteria memiliki tingkat kepentingan yang tidak sama, pembobotannya dapat ditandai dengan w1,w2, ..., wk. Data dasar untuk evaluasi dengan metode Promethee disajikan pada Tabel 1.

TABEL 1

DATA EVALUASI

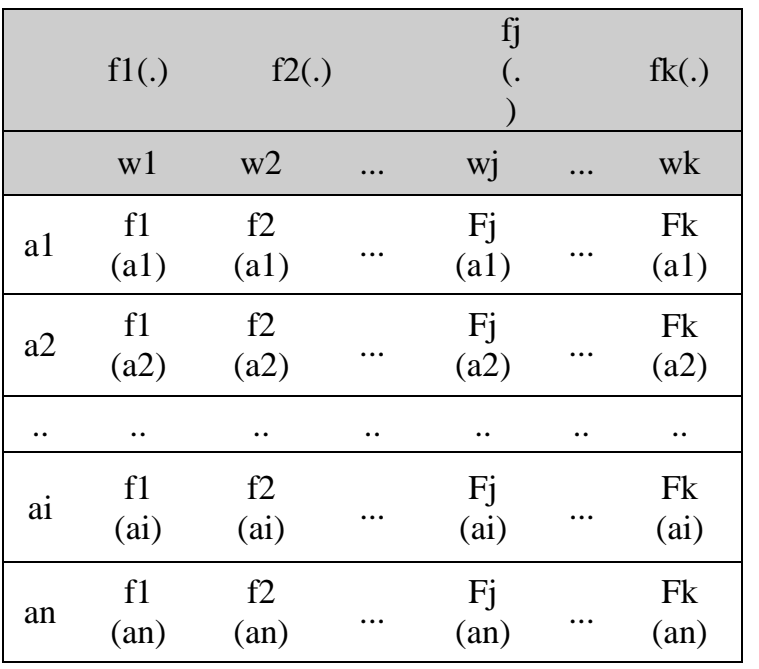

(Sumber: Hunjak (1997:161))

Menurut Hunjak (1997:167), promethee dapat dijelaskan dalam tiga tahapan:

1. Mengumpulkan semua struktur preferensi

Memaparkan kriteria yang dijadikan untuk mendapatkan pertimbangan dari rentang deviasi dalam penilaian sebuah altenatif dari tiap kriteria yang ada.

2. Mengumpulkan relasi yang dominan

Relasi outrangking dibuat sesuai dengan estimasi dari alternatif dari semua kriteria. Total tingkatan dari preferensi adalah suatu alternatif yang mana mendominasi dari hitungan untuk masing-masing pasangan alternatif yang lain.

3. Analisis keputusan

Metode promethee I memberikan sebuah peringkat sebagian dari set A. Informasi akan alternatif yang tidak memiliki tandingan juga telah diberikan. Metode promethee II akan memberikan peringkat yang komplit dari set A.

\section{METODOLOGI PENELITIAN}

\section{A. Langkah-langkah Dalam Penerapan Metode} Promethee

Perhitungan menggunakan metode Promethee ini cukup panjang dalam penerapannya yaitu dengan cara membandingkan setiap alternatif pertama dengan alternatif kedua, alternatif ketiga, dan seterusnya. Adapun langkah-langkah dalam perhitungan Promethee yang digunakan dalam pembuatan keputusan itu sendiri adalah sebagai berikut :
1. Dominasi kriteria yaitu memilih beberapa kriteria dalam perancangan Sistem Pendukung Keputusan ini.

2. Menentukan fungsi preferensi untuk keperluan aplikasi

3. Menghitung Indeks Preferensi Multikriteria

4. Tahap terakhir yaitu Promethee perangkingan

B. Perhitungan Menggunakan Metode Preference Ranking Organization For Enrichment Evaluation (PROMETHEE).

Untuk lebih jelasnya, penulis akan menjelaskan perhitungan menggunakan metode Promethee yang akan dimulai dengan menentukan kriteria terlebih dahulu sesuai dengan studi kasus yang terjadi pada penentuan evaluasi kinerja dosen. Untuk setiap kriteria memiliki bobot yang dapat digunakan sebagai parameter penentuan kelayakan.

Pada kasus ini, tidak ada beda (sama penting) antara a dan $\mathrm{b}$ jika dan hanya jika kriteria $\mathrm{f}(\mathrm{a})=$ f(b); apabila kriteria pada masing-masing alternatif memiliki nilai berbeda, pembuat keputusan membuat preferensi mutlak untuk alternatif memiliki nilai yang baik. Untuk langkah awal yaitu terlebih dahulu tentukan dominasi kriteria dan buat bobot penilaian masing-masing pada kriteria-kriteria tersebut. Dominasi kriteria yaitu memilih beberapa kriteria dalam perancangan Sistem Pendukung Keputusan ini. Adapun kriteria-kriteria sebagai inputannya yaitu pekerjaan, penghasilan per bulan, jumlah tanggungan, dan kondisi fisik bangunan.

\section{1) Kriteria}

Kriteria yaitu memilih beberapa kriteria sebagai kebutuhan pembuatan aplikasi perancangan Sistem Pendukung Keputusan ini. Berikut bobot penilaian pada kasus Sistem Pendukung Keputusan Penentuan penentuan evaluasi kinerja dosen dengan Metode Preference Ranking Organization For Enrichment Evaluation (PROMETHEE).

1. Kriteria Kehadiran

\begin{tabular}{|l|l|}
\hline Kriteria & Bobot \\
\hline Kurang & 50 \\
\hline Cukup & 60 \\
\hline Baik & 70 \\
\hline Sangat Baik & 80 \\
\hline
\end{tabular}

2. Kriteria Pengajaran

\begin{tabular}{|l|l|}
\hline Kriteria & Bobot \\
\hline Kurang & 50 \\
\hline Cukup & 60 \\
\hline Baik & 70 \\
\hline Sangat Baik & 80 \\
\hline
\end{tabular}


3. Kriteria Penelitian

\begin{tabular}{|l|l|}
\hline Kriteria & Bobot \\
\hline Kurang & 50 \\
\hline Cukup & 60 \\
\hline Baik & 70 \\
\hline Sangat Baik & 80 \\
\hline
\end{tabular}

4. Kriteria Pengabdian Masyarakat

\begin{tabular}{|l|l|}
\hline Kriteria & Bobot \\
\hline Kurang & 50 \\
\hline Cukup & 60 \\
\hline Baik & 70 \\
\hline Sangat Baik & 80 \\
\hline
\end{tabular}

5. Kriteria Bimbingan dan konsultasi

\begin{tabular}{|l|l|}
\hline Kriteria & Bobot \\
\hline Kurang & 50 \\
\hline Cukup & 60 \\
\hline Baik & 70 \\
\hline Sangat Baik & 80 \\
\hline
\end{tabular}

6. Tugas Lain Diluar Tugas Utama

\begin{tabular}{|l|l|}
\hline Kriteria & Bobot \\
\hline Kurang & 50 \\
\hline Cukup & 60 \\
\hline Baik & 70 \\
\hline Sangat Baik & 80 \\
\hline
\end{tabular}

7. Tabel hasil penilaian

\begin{tabular}{|l|l|l|l|l|l|}
\hline \multirow{2}{*}{$\begin{array}{c}\text { No } \\
\text { Urut }\end{array}$} & \multirow{2}{*}{ Kriteria } & Nilai & & & \\
\cline { 3 - 6 } & & $\mathrm{A}$ & $\mathrm{B}$ & $\mathrm{C}$ & $\mathrm{D}$ \\
\hline 1 & $\mathrm{~F}(1)$ & 80 & 80 & 70 & 60 \\
\hline 2 & $\mathrm{~F}(2)$ & 70 & 70 & 60 & 70 \\
\hline 3 & $\mathrm{~F}(3)$ & 70 & 60 & 70 & 70 \\
\hline 4 & $\mathrm{~F}(4)$ & 60 & 60 & 70 & 70 \\
\hline 5 & $\mathrm{~F}(5)$ & 70 & 60 & 60 & 80 \\
\hline 6 & $\mathrm{~F}(6)$ & 70 & 70 & 80 & 60 \\
\hline \multicolumn{7}{|c|}{ Jumlah } & 420 & 400 & 410 & 410 \\
\hline
\end{tabular}

2) Menghitung nilai preferensi

Pada tahap ini dilakukan perbandingan antara satu alternatif dengan alternatif lainnya, dengan caramengurangkan nilai alternatif pertamadengan alternatif kedua, kemudian dihitung nilai preferensinya sesuai dengan tipe preferensi yang digunakan. Untuk lebih lengkapnya dapat dilihat pada hasil perhitungan dibawah ini :

\section{$(\mathrm{A}, \mathrm{B})=0+0+1+0+1+0$}

$(\mathrm{B}, \mathrm{A})=0+0+0+0+0+0$

$(\mathrm{A}, \mathrm{C})=1+1+0+0+1+0$

$(\mathrm{C}, \mathrm{A})=0+0+0+1+0+1$

$(A, D)=1+0+0+0+0+1$

$(\mathrm{D}, \mathrm{A})=0+0+0+1+1+0$

$(\mathrm{B}, \mathrm{C})=1+1+0+0+0+0$

$(\mathrm{C}, \mathrm{B})=0+0+1+1+0+1$

$(\mathrm{B}, \mathrm{D})=1+0+0+0+0+1$

$(\mathrm{D}, \mathrm{B})=0+0+1+1+1+0$
$(\mathrm{C}, \mathrm{D})=1+0+0+0+0+1$

$(\mathrm{D}, \mathrm{C})=0+1+0+0+1+0$

3) Menghitung Indeks Preferensi Multikriteria

$(\mathrm{A}, \mathrm{B})=1 / 6(0+0+1+0+1+0)=2 / 6=0.3333$

$(\mathrm{B}, \mathrm{A})=1 / 6(0+0+0+0+0+0)=0$

$(\mathrm{A}, \mathrm{C})=1 / 6(1+1+0+0+1+0)=3 / 6=0.5$

$(C, A)=1 / 6(0+0+0+1+0+1)=2 / 6=0.3333$

$(A, D)=1 / 6(1+0+0+0+0+1)=2 / 6=0.3333$

$(\mathrm{D}, \mathrm{A})=1 / 6(0+0+0+1+1+0)=2 / 6=0.3333$

$(B, C)=1 / 6(1+1+0+0+0+0)=2 / 6=0.3333$

$(\mathrm{C}, \mathrm{B})=1 / 6(0+0+1+1+0+1)=3 / 6=0.5$

$(B, D)=1 / 6(1+0+0+0+0+1)=2 / 6=0.3333$

$(\mathrm{D}, \mathrm{B})=1 / 6(0+0+1+1+1+0)=3 / 6=0.5$

$(C, D)=1 / 6(1+0+0+0+0+1)=2 / 6=0.3333$

$(D, C)=1 / 6(0+1+0+0+1+0)=2 / 6=0.3333$

\begin{tabular}{|c|c|c|c|c|c|}
\hline & $\mathbf{A}$ & B & C & D & $\begin{array}{l}\text { Juml } \\
\text { ah }\end{array}$ \\
\hline $\mathbf{A}$ & & $\begin{array}{l}0.333 \\
3\end{array}$ & 0.5 & $\begin{array}{l}0.333 \\
3\end{array}$ & $\begin{array}{l}1.166 \\
6\end{array}$ \\
\hline B & 0 & & $\begin{array}{l}0.333 \\
3\end{array}$ & $\begin{array}{l}0.333 \\
3\end{array}$ & $\begin{array}{l}0.666 \\
6\end{array}$ \\
\hline $\mathrm{C}$ & $\begin{array}{l}0.333 \\
3\end{array}$ & 0.5 & & $\begin{array}{l}0.333 \\
3\end{array}$ & $\begin{array}{l}1.166 \\
6\end{array}$ \\
\hline D & $\begin{array}{l}0.333 \\
3\end{array}$ & 0.5 & $\begin{array}{l}0.333 \\
3\end{array}$ & & $\begin{array}{l}1.166 \\
6\end{array}$ \\
\hline $\begin{array}{l}\text { Jumla } \\
\text { h }\end{array}$ & $\begin{array}{l}0.666 \\
6\end{array}$ & $\begin{array}{l}1.333 \\
3\end{array}$ & $\begin{array}{l}1.166 \\
6\end{array}$ & $\begin{array}{l}0.999 \\
9\end{array}$ & \\
\hline
\end{tabular}

4) Menghitung Leaving Flow

Leaving flow, digunakan untuk menentukan urutan prioritas pada proses promethee yang menggunakan urutan parsial. Perhitungan ini menggunakan formula (9). Hasil perhitungan Leaving Flow :

$$
\begin{aligned}
& A=1 /(4-1) * 1.1666=0.3889 \\
& B=1 /(4-1) * 0.6666=0.222 \\
& C=1 /(4-1) * 1.1666=0.3889 \\
& D=1 /(4-1) * 1.1666=0.3889
\end{aligned}
$$

5) Menghitung Entering Flow

Selain Leaving flow untuk menentukan urutan prioritas pada proses promethee yang menggunakan urutan parsial juga digunakan perhitungan Entering flow. Perhitungan ini menggunakan formula:

$$
\begin{aligned}
& \mathrm{A}=1 /(4-1) * 0.6666=0.222 \\
& \mathrm{~B}=1 /(4-1) * 1.3333=0.444 \\
& \mathrm{C}=1 /(4-1) * 1.1666=0.3889 \\
& D=1 /(4-1) * 0.9999=0.333
\end{aligned}
$$


6) Menghitung Net Flow

Net flow, digunakan untuk menghasilkan keputusan akhir penentuan urutan dalam menyelesaikan masalah sehingga menghasilkan urutan lengkap.

Page | 126

$$
\begin{aligned}
& A=0.3889-0.222=0.1669 \\
& B=0.222-0.444=-0.222 \\
& C=0.3889-0.3889=0 \\
& D=0.3889-0.333=0.0559
\end{aligned}
$$

Tabel Ranking Metode Promethee Dari tabel dibawah ini dapat dilihat alternatif A mempunyai nilai net flow terbesar yaitu 0.1669

\begin{tabular}{|l|l|l|l|l|}
\hline $\begin{array}{l}\text { Alternat } \\
\text { if }\end{array}$ & $\begin{array}{l}\text { Leavin } \\
\text { g Flow }\end{array}$ & $\begin{array}{l}\text { Entrin } \\
\text { g Flow }\end{array}$ & $\begin{array}{l}\text { Net } \\
\text { Flow }\end{array}$ & $\begin{array}{l}\text { Rangki } \\
\text { ng }\end{array}$ \\
\hline A & 0.3889 & 0.222 & $\begin{array}{l}0.166 \\
9\end{array}$ & 1 \\
\hline B & 0.222 & 0.444 & - \\
& & & 0.222 & 4 \\
\hline C & 0.3889 & 0.3889 & 0 & 3 \\
\hline D & 0.3889 & 0.333 & $\begin{array}{l}0.055 \\
9\end{array}$ & 2 \\
\hline
\end{tabular}

\section{PEMBAHASAN}

a. Tampilan Login

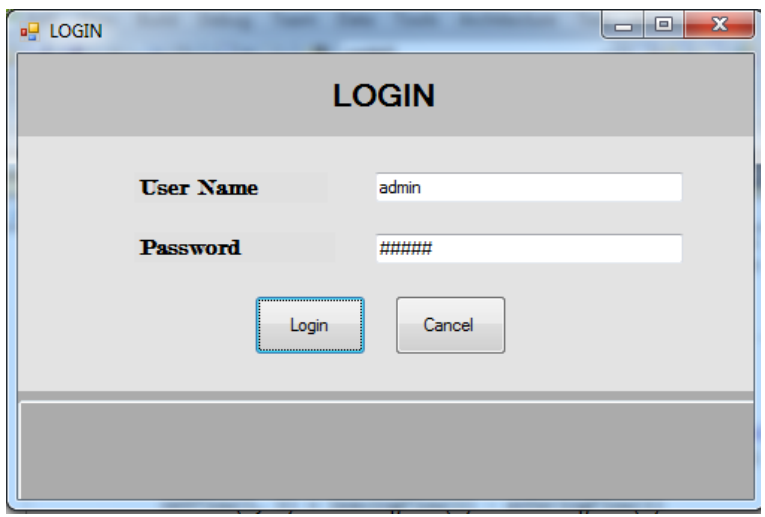

Gbr 1. Tampilan Login

\section{b. Tampilan Halaman Utama}

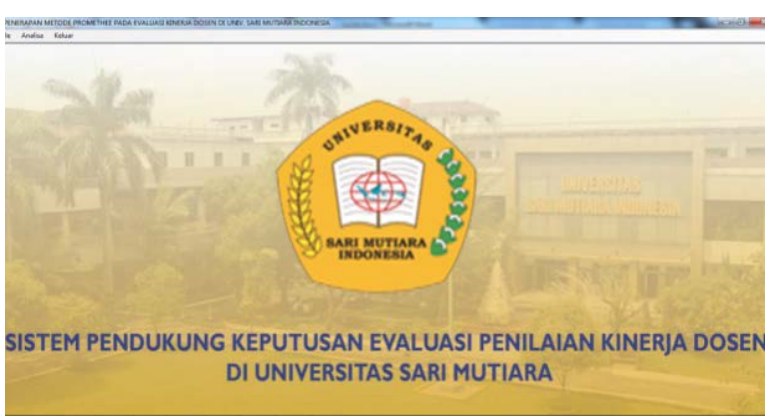

Gbr 2. Tampilan Halaman Utama c. Tampilan Data Kriteria

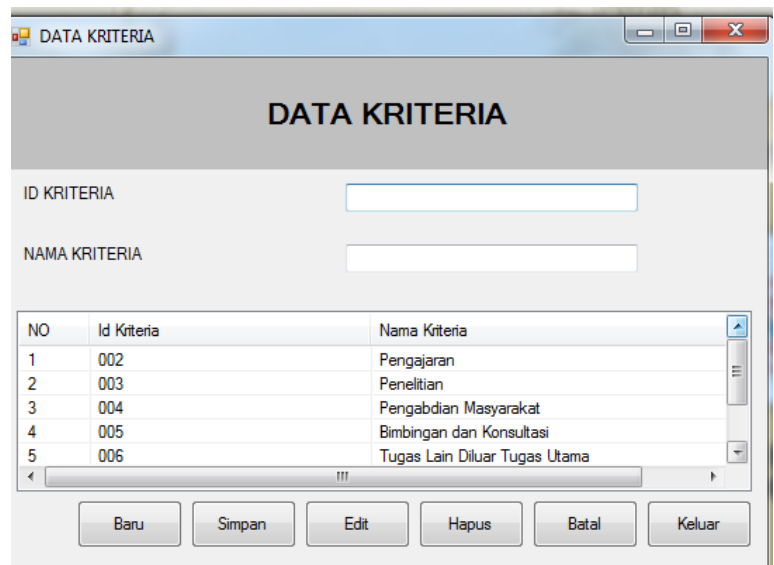

Gbr 3. Tampilan Data Kriteria

\section{d. Tampilan Data Dosen}

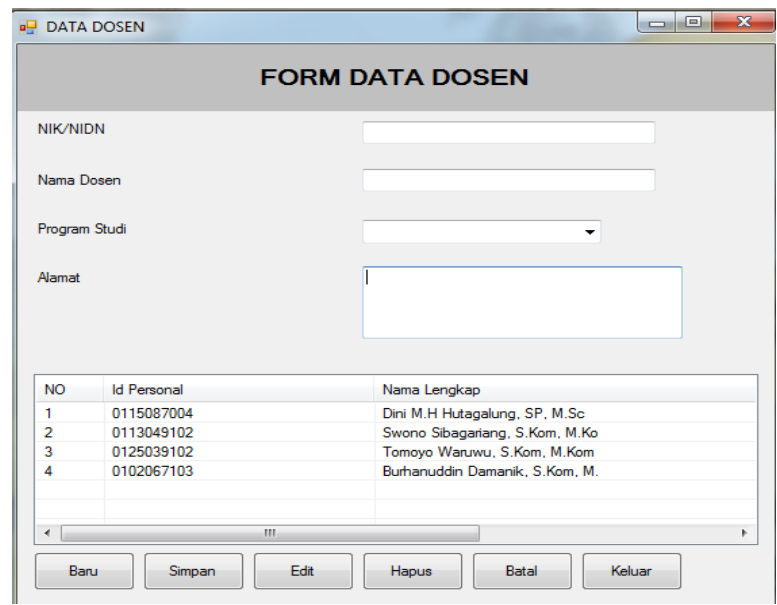

Gbr 4. Tampilan Data Dosen

e. Tampilan Data Penilaian

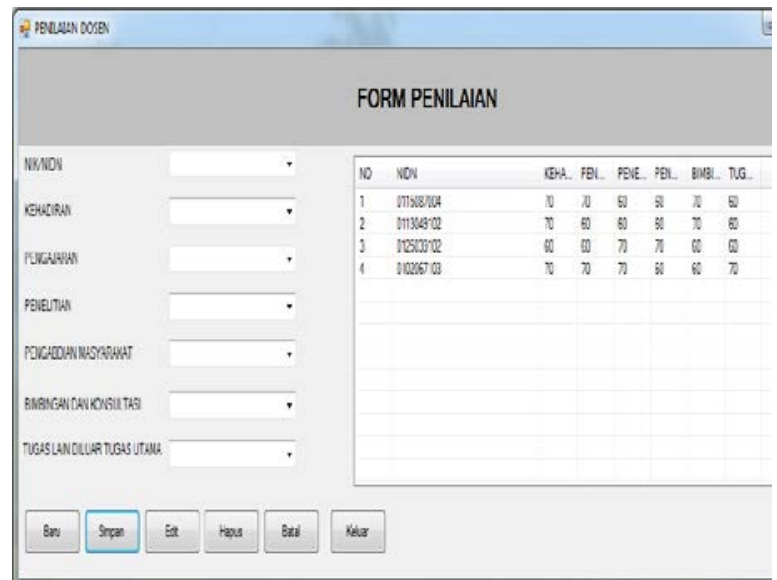

Gbr 5. Tampilan Data Penilaian 


\section{f. Tampilan Hasil Penilaian}

Page | 127

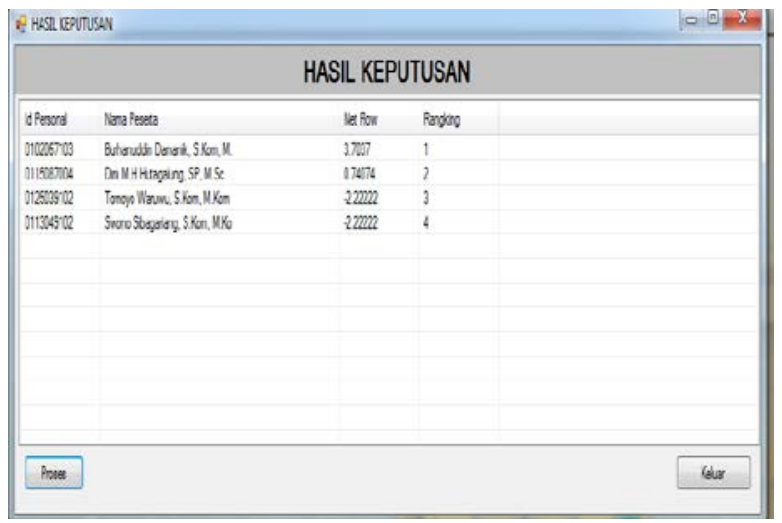

Gbr 6. Hasil Penilaian

\section{PENUTUP}

Berdasarkan hasil analisis, perancangan, dan implementasi, telah berhasil dibangun sebuah sistem pendukung keputusan yang dapat menentukan keputusan secara objektif. Sistem yang telah dibuat mengacu pada rumusan masalah yang ada yaitu sistem dapat menentukan dosen terbaik sesuai ketentuan dengan melakukan perhitungan dengan metode Preference Ranking Organization Method for Enrichment Evaluation (Promethee).

\section{REFERENSI}

[1] Amelia, Pemrograman Sistem Informasi.Surabaya: Sekolah Tinggi Manajemen Informatika \& Teknik Komputer Surabaya

[2] Arhami, Muhammad. 2005. Konsep Dasar Sistem Pakar. Yogyakarta: Andi Offset.

[3] Brans, Jean-Pierre \& Mareschal, Bertrand. Tanpa tahun. How To Decide Promethee. ULB and VUB Brussels Free Universities.

[4] Hasan, I. 2002. Pokok - Pokok Materi Teori Pengambilan Keputusan. Jakarta: Ghalia Indonesia..

[5] Hunjak, Tihomir, 1997, Mathematical foundations of the methods for multicriterial decision making, Mathematical Communications.

[6] Jogiyanto, HM. 1995. Analisa dan Desain Sistem Informasi. Yogyakarta: Andi Offset.

[7] Suryadi K. dan M. A Ramdhani, 1998, Sistem Pendukung Keputusan, PT. Remaja Rosdakarya, Bandung. 